Bell DNF \& Blanchflower DG (2019) The well-being of the overemployed and the underemployed and the rise in depression in the UK. Journal of Economic Behavior and Organization, 161, pp. 180-196

DOI: https://doi.org/10.1016/j.jebo.2019.03.018

(C) 2019, Elsevier. Licensed under the Creative Commons Attribution-NonCommercial-NoDerivatives 4.0

International http://creativecommons.org/licenses/by-nc-nd/4.0/

\title{
The Well-being of the Overemployed and the Underemployed and the Rise in Depression in the UK
}

\author{
David N.F. Bell
}

Division of Economics, Stirling Management School, University of Stirling, IZA and CPC

And

David G. Blanchflower

Bruce V. Rauner Professor of Economics, Department of Economics, Dartmouth College,

Division of Economics, Stirling Management School, University of Stirling,

GLO, Bloomberg and NBER

Monday, March 18, 2019 
Bell DNF \& Blanchflower DG (2019) The well-being of the overemployed and the underemployed and the rise in depression in the UK. Journal of Economic Behavior and Organization, 161, pp. 180-196

DOI: https://doi.org/10.1016/j.jebo.2019.03.018

(C) 2019, Elsevier. Licensed under the Creative Commons Attribution-NonCommercial-NoDerivatives 4.0

International http://creativecommons.org/licenses/by-nc-nd/4.0/

\begin{abstract}
In this paper we build on our earlier work on underemployment using data from the UK. We focus on the effects on well-being of worker dissatisfaction with hours of work. We make use of five main measures of well-being: happiness; life satisfaction; whether life is worthwhile; anxiety and depression. The more that actual hours differ from preferred hours the lower is a worker's wellbeing. This is true for those who say they want more hours (the underemployed) and those who say they want less (the over employed).

We find strong evidence of a rise in depression and anxiety in the years since the onset of austerity in 2010 in the UK that is not matched by declines in happiness measures. The fear of unemployment obtained from monthly surveys from the EU has also been on the rise since 2015 . We report an especially large rise in anxiety and depression among workers in general and the underemployed in particular. The underemployed don't want to be underemployed.
\end{abstract}

JEL codes: I1; I120: I30: I31

Keywords: Underemployment; Overemployment; Well-being; Mental health; Happiness; Depression: Anxiety 


\section{Introduction}

In previous work, we have focused on the extent of underemployment, the characteristics of the underemployed (Bell and Blanchflower, 2011, 2013, 2014, 2018a, 2019), and, most recently, on its role in wage determination (Bell and Blanchflower, 2018b, 2019). Our interpretation of the term underemployment (overemployment) is the expressed wish of employees and the selfemployed to work more (fewer) hours at the going wage rate. We have shown that underemployment increased sharply (and overemployment decreased) after the Great Recession took hold in 2008 across much of Europe.

In the UK, underemployment had not returned to its pre-recession low a decade later at the time of writing, by the fall of 2018, even though the unemployment rate has done so and has reached a 40-year low. We have also shown that the underemployed are typically young, less well-qualified and poorly paid. Finally, arguing that the existence of slack on the internal labor market reduces pressure on employers to increase pay rates in the UK (Bell and Blanchflower 2018b), we have shown that since the Great Recession measures of underemployment enter wage equations significantly negatively for the UK, whereas the unemployment rate is insignificant. We found similar results for the USA (Bell and Blanchflower, 2019).

This paper extends our previous work on both underemployment and overemployment. We show that there are welfare losses from working too many or too few hours. This can be evidenced using several indicators of well-being, such as happiness, life satisfaction, self-worth and depression. We examine data on around 275,000 workers from the UK Annual Population Surveys (APS) from 2013-2018 as well as data on 2.7 million workers from the UK Labour Force Surveys (LFS) from 1997-2018. The APS combines responses to different waves of the UK Labour Force Survey (LFS) and extends the annual sample size to around 320,000. Uniquely, these surveys contain data both on well-being and under and over-employment. For example the equivalent surveys in the United States, the Current Population Surveys (CPS) contain neither. Most previous research on well-being of the underemployed in the UK and elsewhere has used data before the Great Recession so this paper updates that work to the post-recession period.

Using the APS, we find evidence of rising happiness, life satisfaction and how worthwhile life is. In contrast, these same data show that, since 2014, anxiety in the UK has risen. We also present evidence showing a marked rise in depression in the UK since 2010 using LFS data. Increases in both anxiety and depression are especially marked among the underemployed. This evidence of deteriorating mental health is consistent with a growing literature showing a rise in depression in the UK. This includes work by Viola and Moncrieff (2016) who show a dramatic rise in the proportion of people claiming disability benefits for mental disorders in Great Britain.

\section{Underemployment}

\subsection{PTWFT and PTFER}

The simplest underemployment variable that can be constructed from both the APS and LFS uses the "part time-wants full-time" (PTWFT) category which is one possible response to the variable ftptw. This response is used to construct the UK time series in Chart 1. We express this variable as a proportion of employment as this question is only asked of workers; we call this variable U7 (See Bell and Blanchflower, 2019). On the left-hand axis, we plot the unemployment rate and on the right the U7 rate (PTWFT/employment=U7). 
The unemployment rate in 2018 has returned to pre-recession levels. Indeed, the current unemployment rate of $4.0 \%$ at the time of writing in November 2018, was last achieved in February 1975. ${ }^{1}$ In contrast, our new U7 underemployment measure has not returned to its pre-recession level. In July 2018, which is the latest data available, the U7 rate was 3.0\% compared with $2.1 \%$ in April 2008, and a series low since 1992 of 1.8\% achieved in eight separate months from April 2004 through January 2005. The most recent observation was 943,000 for July 2018, down from a high of 1,462,000 in September 2013 and 555,000 in January 2003. The underemployment rate suggests lots of labour market slack, while the unemployment rate does not. We find evidence that post 2008 underemployment imacts wages, while unemployment does not (Bell and Blanchflower,2018b, 2019).

There has also been a marked rise in involuntary part-time employment across advanced countries (Bell and Blanchflower, 2019). It rose during the Great Recession, especially in 2008 and 2009 and has since fallen back. In the US, where we also have monthly data on what is termed "parttime for economic reasons" (PTFER), the latest estimate for October 2018 is 3.0\%. This was up from $2.8 \%$ on the previous month despite the fact that the unemployment rate (U3) fell from $3.9 \%$ to $3.7 \%$. But this U7 series has been as low as $2.2 \%$ in February, April, July and October 2000. Involuntary part-time numbers of those age 15-74 in 2017 were still above their 2008 levels in most EU countries according to Eurostat. In the EU in 2017 there were still nearly nine million underemployed individuals versus under eight million in $2008 .^{2}$

\subsection{Voluntary part-timers and full-timers}

There is a problem with deriving a measure of underemployment solely using the number of parttimers who say they would prefer a full-time job because it excludes other groups of workers who may also be underemployed. For example, full timers who would like to work longer hours are excluded from this measure. In our earlier papers on underemployment, we constructed an underemployment index for the UK for all workers, not just for those who said they were parttime and wanted full-time jobs. Recently, we have also constructed such an index for twenty five other European countries (Bell and Blanchflower, 2019). Unfortunately, no comparable measure is available for the US since the CPS only records workers who say they are part-time for economic reasons (PTFER) which is usually expressed as a proportion of employment or the labor force.

It turns out that not just part-timers who say they can't find a full-time job (involuntary part-timers) but also part-timers who do not want a full-time job (voluntary part-timers) and full-timers want to change their hours. Other groups of part-timers including students also report wanting more hours. The survey questions make clear that desired increases or decreases in hours are at the going wage, and do not involve any change in hourly pay.

The main underemployment questions used are UNDEMP - "Would you prefer to work longer hours at your current basic rate of pay - that is, not overtime or enhanced pay rates -if you were given the opportunity?" and then UNDHRS - "How many extra hours, in addition to those you

\footnotetext{
${ }^{1}$ The Office for National Statistics reports rolling three month averages, so the latest available at the time of writing was for Jun-Aug 2018. In what follows we refer to these three month averages by the middle month so July 2018.

${ }^{2}$ For comparison purposes in July 2018 according to Eurostat there were 13,454,000 unemployed in the EU.
} 
usually work, would you like to work each week?'. The number of hours question is asked of people who say they are not looking for a different job and want more hours, as well as those who say they want a different job with more hours as well as those looking for an additional job. The overemployment question LESPAY is asked of those who say they want more hours. Workers are asked if they would work shorter hours for less pay (LESPAY) and then OVHRS - 'How many fewer hours would you like to work?"3

We are thus able to construct our own overhrs (undhrs) variable for those who say they want less (more) hours at the going wage rate. We impose the rule that only those who say they want to change their hours at the going wage rate are counted as desiring to change their hours. Those who do not wish to increase (decrease) their hours have undhrs (overhrs) set to zero. If individuals express no preference to change their hours, both variables are set to zero.

Questions over hours preferences are asked of all workers, not just of those who are PTWFT. This potentially matters because the data suggests that less than a third of aggregate desired increases in hours come from those who are PTWFT. In the US, only PTFER is available from the Current Population Survey, so it is not possible to measure desired increases or decreases in hours, and therefore impossible to assess the contribution of PTFER to aggregate changes in desired hours.

\subsection{The Bell/Blanchflower Underemployment Index}

We have used these nationally representative data for the UK to construct an underemployment rate each quarter from 2001Q2-2018Q2. We do so by counting the number of hours of those who want more hours and deducting the numbers who want fewer hours and then making unemployment equivalents by dividing through by average hours in the quarter from the LFS data file. Chart 2 plots the aggregates using the sample weights in millions of hours of those who say they want more versus those who want less. Chart 3 shows how these numbers translate into an underemployment rate, which in the years before 2008 was below the unemployment rate but has been above it subsequently.

In the pre-recession period, overemployment was greater than underemployment, because the aggregate reduction in hours due to those wanting fewer hours was larger in absolute size than the aggregate increase in hours due to those wishing to work more hours. That changed in 2008 with the gap between desired additional hours and desired fewer hours widening as the recession took hold. These data suggest that, despite the fact that the gap between the two series has narrowed, significant slack still remains in the UK labor market compared with the pre-recession period. The justification of this assertion is that in the pre-recession years 2001-2008, desired reductions in hours dominated desired increases.

Recently the UK Office of National Statistics (ONS) examined our index and other measures of labour underutilization comparable to the U3-U6 measures constructed by the BLS for the United States see the ONS Economic Review, October 2017, pp. 3-20. They concluded that "the BellBlanchflower method shows how the traditional International Labour Organisation (ILO)

\footnotetext{
${ }^{3}$ The most recent questionnaire for May 2018 is available here http://doc.ukdataservice.ac.uk/doc/8381/mrdoc/pdf/lfs_user_guide_vol2_questionnaire2018.pdf
} 
unemployment rate does not fully capture the increase in labour market slack through underemployment, particularly in the half-decade post the 2008 economic downturn". 4

A recent report by the EU Commission (2018) has also used our index in relation to the EU28. ${ }^{5}$ They argue as follows. "During the crisis, there was also a steady increase in the number of those that wanted to work longer hours (the underemployed). Compared to the common definition of underemployed, in this analysis this group includes both part-time and full-time workers. Building on the work for the UK by Bell and Blanchflower (2013), this box presents an alternative measure of underemployment defined as the underemployment index. It is obtained adding to the (headcount) unemployment, the number of excess supply of hours that workers would like to work at a given wage rate, transformed into unemployment equivalent. Excess supply (the net balance between over-and underemployment) is obtained comparing the desired working hours of the proportion of those that would like to work shorter hours with the proportion of those that would like to work longer hours."

\subsection{Background}

Classical supply models predict that workers who do not find a job which matches their desired combination of wage rate and hours will suffer a welfare loss. However, this prediction sits rather oddly with the observation that workers' weekly hours tend to cluster around particular values such as 38 or 40. In practice, following Lewis (1969), one can think of observed combinations of wage rates and hours as a compromise between workers' willingness to supply labor and firms' demand preferences. In these circumstances, various elements of the employment bargain may be set by "custom and practice" to reduce negotiation costs.

Thus, rather than negotiate separately so that each employee can locate at her welfare-maximizing hours/wage rate combination, firms find it efficient to set hours of work and pay rates for all workers through some process, such as negotiation with worker representatives. They may offer some flexibility around these arrangements, but this will necessarily be limited by the needs of production. Further, employers may vary workers' hours to take advantage of government regulation. For example, in the UK, workers who earn less than $£ 116$ per week are not entitled to sick pay. Blundell and Shepherd (2010) describe the complexity of such employment regulations that directly or indirectly interact with hours of work for different household types.

Another cause of departure from employee's optimal working time can arise from unexpected fluctuations in product demand. When faced with such fluctuations, employers may decide to impose changes to workers' hours, hoping that such variation is temporary (see Oi, 1982). From the employer perspective, this response is less costly than varying productive capacity by hiring or firing workers particularly when there is joint investment in specific human capital. Of course, for the self-employed, there is a much closer link between product demand and working time. The UK has a relatively high proportion of self-employed $-14.8 \%$ of the workforce (Blanchflower,

\footnotetext{
4 The Bank of England has been using our underemployment index as reported in various of its quarterly inflation reports such as May 2014 and May 2015, Chart 3.15. For a discussion regarding the appropriate way for the Bank of England to treate underemployment with MPC member Weale (2014) in Bell and Blanchflower (2015).

${ }^{5}$ In particular see Box 1.1.2.
} 
2015). In 2013/14, their median annual earnings adjusted for inflation were $22 \%$ lower than they were in 2007/2008 (Source: ONS, 'Self-employed workers in the UK, 2014).

Thus, for a variety of reasons, including firm custom and practice, the regulatory environment and firm response to variations in demand, workers may find themselves "underemployed". Similarly, some may find themselves "overemployed". Whatever the reason, the outcome may be less than ideal from their perspective. And the standard theory would still predict that the greater the gap between the hours that workers would prefer and those that they are offered, the greater their welfare loss. This might be manifest in a number of ways. These might include lower life satisfaction, less happiness, more anxiety, poorer mental health, and possibly poorer physical health. Those who want to work fewer hours may also experience such negative consequences.

In an earlier paper using the LFS from 2001-2010, Tam (2010) from the ONS noted that underemployment "was more prevalent in the part-time than full-time workforce and in those whose usual weekly hours were fewer than 30 hours a week. Compared to their older counterparts, younger people, particularly 16 to 17-year old males, were more likely to be underemployed. In both the part-time and full-time workforce, men were more likely than women to be underemployed. Underemployment was also more common in people with lower levels of qualifications, people working in the 'distribution, hotels and restaurants' industry, and employed in 'elementary' occupations. Due to their insufficient hours, the underemployed also earned less income than those who were adequately employed or overemployed." (p.19).

\section{Results}

Table 1 reports our estimates of the proportion of workers who are underemployed and overemployed and the number of additional or fewer hours they report they desire. The first column is the U7 measure which expresses those who are PTWFT as a percent of employment, which rose from 2008 to a peak around 2013 and then declined but still remains above 2008 levels. In the second column, we report the share of the workforce who report they want one or more additional hours, and in column 3 the mean additional hours of those who want one or more hours, both of which have roughly the same path as U7. The fourth column show the decline in the share of those who want fewer hours through 2012 and then a steady rise subsequently, although the mean reduction in hours desired by this group rose through 2013 and then fell back to pre-recession levels.

In a new study for the UK Datta et al (2018) found, in a survey of workers on zero-hours contracts (contracts with no guaranteed hours of work), there was an almost even split between workers who are satisfied with their number of hours (40 percent) and workers who would rather work more hours (44 percent), while a remaining 16 percent wanted to work fewer hours. Of those wanting to work more hours, 74 percent pointed to the lack of available work.

In Bell and Blanchflower (2018a) we estimated a two-part model relating to the characteristics of the underemployed and the over-employed. The first part is a probit model that seeks to identify those variables associated with the probability of a worker seeking increased working time. Thus, the dependent variable takes the value one if the respondent expresses a wish to work more hours in the relevant quarter, and zero otherwise. The second part is a regression model that identifies characteristics associated with the quantity of additional hours desired, conditional on expressing 
a wish to extend working time. The dependent variable is thus the number of hours that those expressing a wish to work longer would like to work. We estimated this two-part model for the pre-recession period, 2002-7 and the subsequent slow economic recovery between 2008 and 2017.

For the period 2001-7, our probit estimates showed that workers aged 16 to 49 were significantly more likely to express a wish to increase their hours at their current pay rate than those aged 50+, while the same group was significantly more likely to wish for hours reductions. Similarly, qualifications have a symmetrical effect. The less qualified are more likely to wish to increase their hours, and they were less likely to desire a reduction in their working time. Similarly, those with shorter tenures were more likely to wish to increase their working time whereas those who have more than ten years tenure are more likely to seek fewer hours. Long-tenure may imply a successful job match which in turn reduces the demand for additional hours. However, this explanation fails to capture why long tenure workers are significantly more likely than those with short tenures to seek fewer hours.

Females, we found, were somewhat more likely than males to seek longer working hours, but they are also more likely to seek fewer hours. Being married reduced the probability of seeking more hours and increases the desire for fewer hours. Workers born outside the UK are significantly more likely to seek more hours and significantly less likely to wish to reduce their hours. Finally, the self-employed are more likely to seek increases in their working time and less likely to wish to reduce their hours.

\section{Well-being}

4.1. Life satisfaction, Happiness, Worthwhileness and Anxiety

Having established who the underemployed and the overemployed are, we now examine the wellbeing of both underemployed and overemployed workers in the UK. Since 2011, the APS has contained four questions that can be used to assess well-being, but questions on desired hours are only available from 2013-2017 so we restrict our sample to those years. Note that these questions are only reported in the APS and not the LFS data sets. The questions are:

Q. Next, I would like to ask you four questions about your feelings on aspects of your life. There are no right or wrong answers. For each of these questions I'd like you to give an answer on a scale of nought to 10, where nought is 'not at all' and 10 is 'completely'.

1. Overall, how satisfied are you with your life nowadays?

2. Overall, to what extent do you feel that the things you do in your life are worthwhile?

3. Overall, how happy did you feel yesterday?

4. On a scale where nought is 'not at all anxious' and 10 is 'completely anxious', overall, how anxious did you feel yesterday?

The weighted percentage distributions, with the sample restricted to workers are as reported in Table 2 over the years 2013-2017. The majority of workers report scores of seven or higher to the happiness, satisfaction and worthwhileness questions. The vast majority report being happy, 
satisfied with their lives which they say are worthwhile. It is notable that $29 \%$ of respondents report a score of zero on the anxiety scale and half give scores of two or lower.

The correlation between these measures among workers, weighted, is reported in Table 3. It is reasonably high $(\mathrm{n}=276,780)$. The highest of .621 being between worthwhileness and satisfaction.

Table 4 shows well-being by labour force status. On each measure, it is lowest for the unemployed and next lowest for those who are PTWFT. The second part of the table reports well being by the number of hours the underemployed say they want to increase their hours by, while the third part reports well being by the number of hours the overemployed say they want to reduce their hours by. Well-being is lower, the greater the gap between actual and desired hours for both the overand under-employed.

Table 5 shows that happiness, life satisfaction and worthwhileness have grown steadily over time. This is consistent with evidence from the Eurobarometer surveys for the UK as reported in the World Database of Happiness which have also shown a steady rise in life satisfaction. ${ }^{6}$ In contrast, anxiety, which is shown in the final column, declined from 2.89 in 2013 to 2.78 in 2015 but subsequently increased to 2.85 in $2017 .{ }^{7}$ Analogously, as we show below, we find a steady rise in depression since around 2010. The recession does not seem to have been happiness reducing but it was unhappiness increasing.

\subsection{Prior Literature on Underemployment and Well-being}

There have been some previous studies of underemployment and well-being. For the UK. Kamarade and Richardson (2018) use APS data for 2012-2013 and examine whether involuntary part-timers have lower well-being in the UK. They find that well-being is not significantly lower for men with under one year of tenure for happiness, life satisfaction or anxiety and only for women with short tenure in life satisfaction. The sample sizes in their study are small, with around 4000 observations. For those with tenure of more than a year, they find significant negative effects for men only in life satisfaction and for women in both happiness and life satisfaction. One difficulty with this analysis is that women are more likely to be part-time than men.

Heyes et al (2017) examined the 2006 and 2012 Skills and Employment Survey in Britain and measured well-being along 'enthusiasm-depression' and 'contentment-anxiety' axes. They showed lower scores on the scales if workers were dissatisfied with the working time on offer. This includes both working too few, or too many, hours. They also found there was a decline in wellbeing between 2006 and 2012 as recession hit. Their main finding though is that "workers who

\footnotetext{
6 The average life satisfaction scores in the World Database of Happiness for the UK using the four point scale from the question 'On the whole how satisfied are you with the life you lead? $4=$ very satisfied; $3=$ fairly satisfied; $2=$ not very satisfied and $1=$ not at all satisfied were as follows - and averaged across estimates if there was more than one . $2001=3.17 ; 2002=3.14 ; 2003=3.16 ; \quad 2004=3.22 ; \quad 2005=3.21 ; \quad 2006=3.21 ; \quad 2007=3.21 ; \quad 2008=3.18 ; \quad 2009=3.28$; $2010=3.27 ; 2011=3.26 ; 2012=3.28 ; 2013=3.26 ; 2014=3.34 ; 2015=3.35 ; 2016=3.39 ; 2017=3.37$

https://worlddatabaseofhappiness.eur.nl/hap_nat/nat_fp.php? cntry $=16 \&$ name $=$ United $\% 20$ Kingdom $\&$ mode $=3 \&$ subje cts $=1139 \&$ publics $=129$

${ }^{7}$ See ONS Measuring National Well-being: Anxiety

https://www.ons.gov.uk/peoplepopulationandcommunity/wellbeing/datasets/measuringnationalwellbeinganxiety
} 
are underemployed experience lower well-being levels than those who are more adequately employed". (p.84).

Angrave and Charlwood (2015), make use of longitudinal data from waves 1 to 18 of the British Household Panel for working age adults from 18-65 for the year 1991-2008. The question used is similar to the question in the LFS. 'Think about the hours you work, assuming that you would be paid the same amount per hour, would you prefer to work fewer hours, more hours, or the same number of hours?". They also find that overemployment and underemployment are associated with lower well-being. In regressions for job satisfaction, life satisfaction and a GHQ score that include people fixed effects, they find underemployment lowers well-being as does overemployment. Well-being falls if there is a mismatch between actual and preferred hours; long working hours in themselves are not associated with lower subjective well-being.

Wilkins (2007) examined longitudinal data from the 2001 Household, Income and Labour Dynamics in Australia (HILDA) survey and found that underemployment is associated with lower life and job satisfaction. Indeed, he found that well-being losses for part-time workers seeking full-time employment 'are, for some outcomes, not far short of those attributable to unemployment'. Wooden, Warren and Drago (2009) also find that underemployment lowers job and life satisfaction using the HILDA data.

Robone et al (2011), using the BHPS for the UK, found that both contractual and working conditions have an influence on health and psychological well-being. Wunder and Heineck (2013) found for Germany from the GSOEP that well-being is generally lower among those with working time mismatch. They found that underemployment is particularly detrimental for wellbeing.

\subsection{Consequences of Underemployment}

There is some evidence also on the consequences of underemployment. However, these have to be treated with caution: statistical associations between underemployment and health may result from any of the following underlying causal conditions: (1) underemployment affects health; (2) health affects the probability that a person will be underemployed; and (3) unobservables affect both underemployment and health (Zapf, Dormann and Frese, 1996).

Dooley et al (2000) analyzed panel data from the National Longitudinal Survey of Youth for the years 1992-1994 for the 5,113 respondents who were adequately employed in 1992. Controlling for prior depression, shifts from adequate employment to underemployment resulted in significant increases in depression. The direct effects that they found, which were similar to moving from employment to unemployment, persisted despite inclusion of such potential mediators as changes in income, job satisfaction, and marital status. Prior depression did not predict higher risk of becoming inadequately employed but did predict increased risk of unemployment, particularly for those with less education.

Prause and Dooley (1997) find that underemployment lowered self-esteem, while Dooley and Prause (1998) find that it led to increases in symptoms of alcohol abuse. Friedland and Price (2003) using longitudinal data for the US from the Americans Challenging Lives Study from 1986- 
1994, discover that underemployed workers report lower levels of health and well-being than adequately employed workers.

\section{Well-being Results}

Table 6 estimates a series of well-being equations with controls that are standard in the literature - gender, age, race, industry and location. Well-being is higher among the foreign born, the selfemployed, those with a degree, women, Asians and for those with longer tenure.

It should be noted that the year dummies in the happiness and life satisfaction increase steadily over time. In the worthwhile equation, they turn down in 2017 and turn up, in the anxiety equation in 2016 and 2017, showing increased anxiousness. This decline in well-being has occurred at the same time as there has been an increase in the fear of unemployment (Blanchflower, 1991 and Blanchflower and Shadforth, 2009). In the European Commission's Consumer survey, individuals are asked what they think will happen to unemployment over the next year and a qualitative score is calculated. ${ }^{8}$ The higher the score the more the expectation is that unemployment will rise. This index for the UK rose to a high of 75.3 in January 2009 dropping steadily subsequently to a low of -0.3 in October 2014 but has risen subsequently to 22.1 in June 2018 before falling back to 17.2 in October 2018 but then rising steadily since then to 25.4 in February 2019. Notably over this four-year period the unemployment rate fell from $5.9 \%$ to $4.0 \%$. UK residents are increasingly anxious and fearful of losing their jobs.

The underemployed and the overemployed are both unhappy. The larger the size of the desired change in hours lowers the levels of well-being in all four equations. A one-hour desired increase in working time has approximately the same negative effect on happiness and anxiety as does a one-hour desired reduction in working time. However, life satisfaction and seeing life as worthwhile are much more sensitive to those who wish to increase their hours than to those who seek a reduction in hours.

It does seem that the size of the effects on well-being in Table 8 are large from both under and overemployment and broadly consistent with the mean estimates in Table 6. The coefficient on under hours (-0.153) in Table 6 implies that the change from being satisfied with one's hours of work to wishing to work an additional 11.3 hours (the mean increase in hours desired by the underemployed in 2018 - see Table 1), is associated with a reduction in happiness of 1.7 "happiness points" on its 10 point scale. Similarly large effects are also apparent from the other three well-being variables for underemployment and especially so with life satisfaction where the effects are nearly twice as large. The effects from fewer hours of overemployment are also substantial but smaller.

Each of the equations in Table 6 shows the four well-being variables by age and each is supportive of a U-shape in well-being for workers and an inverted U-shape for anxiety. Happiness, life satisfaction and worthwhileness minimize in the age range 50-54 while the anxiety variable reaches a maximum at the same age. That is consistent with the findings of a U-shape in happiness and well-being across many countries including the UK in Blanchflower and Oswald (2008, 2018).

\footnotetext{
8 The data rose as follows from October 2018 - 17.2; Nov-18 18.3; Dec-18 22.9; Jan-19 23.4; Feb-19 25.4 https://ec.europa.eu/info/business-economy-euro/indicators-statistics/economic-databases/business-and-consumersurveys/methodology-business-and-consumer-surveys/methodological-guidelines-and-other-documents en
} 
Finally, Blanchflower and Oswald (2016) find an inverted U-shape across countries in the consumption of anti-depressant medications. See also Rauch (2017).

\section{Depression}

\subsection{Depression in the UK Labour Force Survey}

Since 1997, respondents to the quarterly LFS have been asked to report their main health problem, if any. We examined LFS data from January 2013 to April 2018, which has 1,624,298 weighted observations, on those sixteen years of age and over for the latest estimates. Overall $62.8 \%$ say they have none. Two options are available that relate to mental health - a) depression or bad nerves, which accounts for $2.8 \%$ of the total and b) mental illness, phobia, panics or $1.15 \%$ of the total. They are $2.2 \%$ and $0.5 \%$ of workers respectively and $3.3 \%$ and $0.8 \%$ for the underemployed (undhrs $>0$ ) and $2.4 \%$ and $0.3 \%$ for the overemployed (ovhrs $>0$ ). Thus the underemployed are especially likely to report being depressed, although the direction of causality remains unclear.

The weighted distribution of being depressed, by labor force characteristics is reported in Table 7 , (all using standard LFS weights). It is apparent that, just as they were disproportionately anxious, the underemployed are more depressed than other workers, with the rates being higher for men than women. The proportion is less than for the unemployed but still well above male and female voluntary part-timers and full-timers. Again, the larger the gap between actual and desired hours (under or over), the higher the probability of being depressed.

Table 8 shows the incidence of depression by year using micro-data from the LFS from 1997-2018 (April) with sample weights imposed. It shows that depression is especially high among the unemployed in every year (Blanchflower, 2019). It also shows that the rise in depression especially since 2011 which is coincidental with the onset of austerity imposed by the UK Chancellor George Osborne in the Budget of June 2010.

The probability of being depressed rises especially rapidly for the underemployed, for men and especially so for underemployed women. Between 2008 and April 2018 real wages in the UK fell by $6.5 \%$. It is not surprising then to find that over this same period the incidence of depression among workers has nearly quadrupled while that of the unemployed and those who are OLF has not increased by that much. The incidence of depression among the underemployed has increased more than fourfold - from $1.1 \%$ in 2008 to $4.8 \%$ in 2018.

Chart 4 plots the probabilities of being depressed overall, for workers and for the underemployed who want at least one more hour of work at the going wage. There are obvious inverted U-shapes overall, for workers, and for the underemployed. There is no such inverted U-shape in depression for the overemployed, which slopes down in Chart 5. The inverted U-shape in age using LFS data on depression, for the period 2004 Q2-2007 Q1 was first reported in Blanchflower and Oswald (2008). As noted above it was also apparent for all four well-being measures in Table 8.

\subsection{Evidence on Rising Depression in the UK}

Supporting evidence on the rise in mental disorders in the UK is recent work by Viola and Moncrieff (2016). They examined data from the Department of Work and Pensions regarding numbers of claimants of all sickness and disability-related benefits in England, Scotland and Wales. They reported that mental disorders in the UK have become the most common cause of 
receiving benefits, with the number of claimants rising by $103 \%$ from 1995 to 1.1 million in 2014 . Claimants with other conditions, they reported, fell by 35\%. In 2014, 47\% of claims were attributed to a mental disorder. The number of long-term claimants claiming over 5 years with mental disorders increased by $87 \%$ from 2000 to 2011. Two-thirds of mental disorder claimants were classified as having a depressive or anxiety disorder.

A recent article by Baxter et al (2014) has challenged the idea that there has been a rise in mental disorders and argued that it is a 'myth'. They argued first that the rise in the incidence of mental disorders was due to the fact that population had risen. But that can be dealt with simply by expressing the To clarify, we observed in Table 6 that depression as a proportion of the population, and as a proportion of workers, the unemployed and those who were out of the labor force had risen, so that seems to deal with that problem. They also claimed that changing age structures explained by changing age structures. We find that is also not true in the data for the UK. The rise of depression and anxiety in the UK does not seem to be a myth.

Table 9 reports the probit probabilities of a British worker being depressed. Results are presented for 2004-2017 for all workers ages sixteen and over. The overall sample size is 2.74 million workers. Controls are included for age, gender, race, education, self-employed and region of work plus fourteen year-dummies. Depression follows an inverted U-shape in age that maximizes in the age band 40-44 years in both equations. The higher the gap between actual and desired hours, the higher is the probability of being depressed.

The rise in the size of the coefficients over time suggests that the rise in depression especially, which was apparent in the means in Table 8 continues when controls are included. The second column relates to the underemployed, and is again determined by whether they report they want to increase their hours by at least one hour a week (undhrs $>0$ ). The third column does the same for the overemployed (ovhrs $>0$ ). The increase in the size of the coeffieients in the year dummies is especially marked for the underemployed, implying that depression among this group has grown more raidly than among all workers, or the overemployed, since 2008.

There is also evidence of a rise in depression in the UK from the Adult Psychiatric Morbidity Survey: Survey of Mental Health and Wellbeing, England, $2014^{9}$ The survey reports that between 2007 and 2014 the proportion of respondents with a 'depressive episode' rose from $3.7 \%$ in 2007 to $4.5 \%$ in 2014 . They saw only a small rise in phobias from $2.2 \%$ to $2.7 \%$. This is similar to the data from the LFS we report above, that also contains information on 'mental illness, phobia, panics' which was another option in relation to an individual's main health problem. That rose only slightly, from $0.7 \%$ in $2004-2007$, to $1.0 \%$ in 2013 and to $1.2 \%$ in $2016-2018$.

Consistent with our evidence the UK Council of Psychiatry reported that anxiety and depression hit a record high in 2017, with part-time workers especially bearing the brunt. Part-timers in their report experienced a rise in anxiety between 2013 and 2017 of a third. ${ }^{10}$

\footnotetext{
${ }^{9}$ https://digital.nhs.uk/data-and-information/publications/statistical/adult-psychiatric-morbidity-survey/adultpsychiatric-morbidity-survey-survey-of-mental-health-and-wellbeing-england-2014

${ }^{10}$ Mary Bulman, 'Anxiety and depression among UK workers up nearly a third in four years, figures show', The Independent, $10^{\text {th }}$ October 2017.
} 


\subsection{The Rise in Anti-depressant Prescribing}

Consistent with the rise in depression, the use of anti-depressants is also on the rise (Blanchflower and Oswald, 2016). The English National Health Service published a report entitled "Prescriptions Dispensed in the Community - Statistics for England 2006-2016", which reported that the total number of anti-depressant drugs dispensed in England was nearly 65 million in 2016, an increase of $108.5 \%$ from its 2006 level of 31 million. As can be seen in Table 10, consumption of antidepressant drugs has doubled in OECD countries between 2000 and 2015 (OECD Health at a Glance 2017). Anti-depressant prescriptions in the UK increased two and a half times over the fifteen year period.

Mars et al (2017) examined trends in antidepressant prescribing in the UK between 1995 and 2011 among one and a half million patients from the Clinical Practice Research Datalink, a large anonymized primary care database in the UK. Antidepressant prescriptions, Mars and co-authors found, rose from 61.9 per $1000 \mathrm{PY}$ in 1995 to 129.9 per $1000 \mathrm{PY}$ in 2011. In contrast, incidence rates of those starting antidepressants remained relatively stable (1995: 21.3 per 1000 PY; 2011: 17.9 per $1000 \mathrm{PY})$. The duration of treatment increased, the authors noted, with later starting years, with an increasing proportion of long-term use, and decrease in short-term use. The results are thus not driven by an increased number of people starting medication but by an increase in the duration of treatment.

In the US between 2011 and 2014, Pratt et al (2017) showed that approximately one in eight Americans of all ages reported taking at least one antidepressant medication in the past month, according to national survey data released by the Centers for Disease Control and Prevention (CDC). Antidepressant use in the past month increased overall, from 7.7\% in 1999-2002 to 12.7\% in 2011-2014. Non-Hispanic whites were more likely to take antidepressants than non-Hispanic black, Hispanic, and non-Hispanic Asians.

It is a matter of debate what the counterfactual is in the absence of the rise in prescriptions. Jorm et al (2017) report that the increased provision of treatments and antidepressants has not reduced the prevalence of depression, though their main explanation seems to be that the treatments don't work. Indeed, for England they argue that the evidence suggests 'England has had an increasing use of antidepressants, hypnotics and possibly talking treatments since 1993. However, there is no evidence for any decrease in prevalence of disorders or reduction of symptoms in adulthood. If anything, trends are in the opposite direction' (2017, p.92). We find no decreases in the prevalence of depression despite the rise in treatments.

\section{Concluding Remarks}

Our work suggests that underemployment now accounts for almost as many hours "lost" to the UK economy as does unemployment. Our estimates from the UK LFS for 2018 Q2 imply that the underemployed would be willing to supply an additional 34 million weekly hours at their current wage. Assuming that in July 2018, the 1.36 million unemployed work the average weekly hours of all workers (32.1 hours per week), the hours "lost" through unemployment amount to a further 44 million hours per week. The July 2018 unemployment rate was 4.0\%, but adding these additional underemployed equivalents increases the actual rate of slack in the UK labour market to 78 million hours per week which is the equivalent of a $7.0 \%$ unemployment rate. No wonder 
there is benign wage growth. Prior to 2008, the number of underemployed workers calculated in this way was not as close to the number of unemployed.

These underemployed workers help to keep wage growth in check. Elevated levels of underemployment suggest the UK economy is nowhere close to full-employment in the summer of 2018 , even though the unemployment rate at the time of writing is $4.0 \%$.

Note that in line with Angrist (2001), we do not interpret our results as implying causality. As a referee has noted, it is appropriate to ask if there something about underemployed workers that makes them both more likely to be insufficiently employed and to be depressed/unhappy? Do low levels of belief that life is worthwhile drive unsatisfactory jobs, or does causality run in the opposite direction? It may be hard to imagine that such a large pool of people share unhappy traits that then cause them to find worse jobs, but our results cannot rule out this possibility.

What our results do show is that the unemployed are unhappy and to a lesser extent so are the underemployed. Part-timers who want full-time jobs have lower levels of well-being than voluntary part-timers or full-timers. This may partly stem from the loss of earnings and lower living standards that hours rationing imposes on workers. We also find that both the greater the gap between desired and actual hours, the greater the likelihood of unhappiness and depression among both the underemployed and the overemployed.

We find strong evidence of a rise in depression and anxiety in the last decade that is not matched by declines in happiness measures. We also report an especially large rise in anxiety and depression among the underemployed since the onset of austerity in 2010 . The decline in wellbeing of workers occurs over the period when real wages in the UK declined by $6 \%$ from February 2008 through August 2018. The increase in depression among the underemployed since 2008 is greater than that for the unemployed or for those who are out of the labor force. Underemployment hurts. 
Table 1. Time series of underemployment and overemployment, 2008-2018

\begin{tabular}{|c|c|c|c|c|c|}
\hline & U7 & $\%$ under hrs $>0$ & $\begin{array}{l}\text { Number of } \\
\text { under hours }\end{array}$ & $\%$ overhours $>0$ & $\begin{array}{l}\text { Number of } \\
\text { over hours }\end{array}$ \\
\hline 2008 & 2.5 & 9.0 & 11.6 & 9.2 & 10.8 \\
\hline 2009 & 3.4 & 11.0 & 11.7 & 8.7 & 10.8 \\
\hline 2010 & 3.9 & 11.8 & 11.8 & 9.3 & 10.8 \\
\hline 2011 & 4.4 & 11.9 & 12.0 & 8.7 & 11.0 \\
\hline 2012 & 4.9 & 12.2 & 12.2 & 8.6 & 11.1 \\
\hline 2013 & 4.9 & 12.3 & 12.3 & 8.8 & 11.3 \\
\hline 2014 & 4.5 & 11.7 & 12.1 & 9.4 & 11.2 \\
\hline 2015 & 4.1 & 11.1 & 11.8 & 9.7 & 11.1 \\
\hline 2016 & 3.7 & 10.4 & 11.9 & 10.1 & 11.2 \\
\hline 2017 & 3.2 & 10.0 & 11.8 & 10.0 & 11.1 \\
\hline 2018 & 3.1 & 9.7 & 11.3 & 10.1 & 10.9 \\
\hline
\end{tabular}

Source: LFS; weighted using the variable pwt. Notes: column 1 - U7 relates to the percent of workers who say they are part-time but want a full time job (PTWFT/Employment). Column 2 refers to the percent who want $>0$ more hours. Column 3 reports average hours of those who say they want more hours (undhrs $>0$ ). Colun 4 reports the percent of workers who say they want fewer hours (ovhrs $>0$ ). Column 5 reports average fewer hours workers say they want if they want more hours (ovhrs $>0$ ).

Table 2. Distribution of well-being scores

$\begin{array}{lcccc} & \text { Happy } & \text { Satisfied } & \text { Worthwhile } & \text { Anxious } \\ \text { Not at all } & 1 & 0 & 0 & 29 \\ 1 & 1 & 0 & 0 & 10 \\ 2 & 1 & 0 & 0 & 15 \\ 3 & 2 & 1 & 1 & 10 \\ 4 & 3 & 1 & 1 & 7 \\ 5 & 8 & 6 & 4 & 10 \\ 6 & 9 & 7 & 6 & 6 \\ 7 & 17 & 21 & 19 & 6 \\ 8 & 26 & 36 & 34 & 4 \\ 9 & 17 & 15 & 18 & 2 \\ \text { Completely } & 16 & 12 & 16 & 1 \\ \text { Mean } & 7.53 & 7.74 & 7.96 & 2.84 \\ \text { N } & 277,658 & 277,716 & 277,224 & 277,459\end{array}$

Sources: APS 2013-2017 weighted with variable $p w t$

Table 3. Correlation between well-being measures $(n=276,780)$.

Happy

Happy

1.0000

Satisfied

.5373
Satisfied Worthwhile

Anxious

1.0000 
Worthwhile

$\begin{array}{lll}.4595 & .6207 & 1.0000\end{array}$

Anxious

$-.4515$

$-.3206$

$-.2376$

1.000 
Table 4. Well-being by labor force status and \# under and over hours, January 2013-December 2017. $N=510,293$

$\begin{array}{lcccc} & \text { Happy } & \text { Satisfied } & \text { Worthwhile } & \text { Anxious } \\ \text { Workers } & 7.53 & 7.53 & 7.96 & 2.84 \\ \text { PT wants full-time } & 7.24 & 7.22 & 7.59 & 3.17 \\ \text { PT does not want full-time } & 7.71 & 7.89 & 8.18 & 2.79 \\ \text { Full-time } & 7.50 & 7.73 & 7.91 & 2.82 \\ \text { Unemployed } & 6.95 & 6.72 & 7.16 & 3.44 \\ \text { Out of the labor force } & 7.49 & 7.57 & 7.78 & 2.96 \\ & & & & \\ \text { Workers only } & & & & \\ \text { Under hours=0 } & 7.55 & 7.78 & 7.99 & 3.14 \\ \text { Under hours 1-4 } & 7.50 & 7.60 & 7.92 & 3.13 \\ \text { Under hours 5-9 } & 7.42 & 7.54 & 7.82 & 3.17 \\ \text { Under hours 10-19 } & 7.34 & 7.37 & 7.75 & 3.31 \\ \text { Under hours } \geq 20 & 7.22 & 7.10 & 7.55 & \\ & & & & 2.80 \\ \text { Over hours=0 } & 7.55 & 7.74 & 7.97 & 3.08 \\ \text { Over hours 1-4 } & 7.42 & 7.79 & 7.86 & 3.13 \\ \text { Over hours 5-9 } & 7.43 & 7.76 & 7.87 & 3.18 \\ \text { Over hours 10-19 } & 7.36 & 7.71 & 7.90 & 3.28 \\ \text { Over hours } \geq 20 & 7.25 & 7.60 & 7.88 & \end{array}$

Table 5. Changes in well-being over time of workers (weighted).

$\begin{array}{lcccc} & \text { Happiness } & \text { Satisfaction } & \text { Worthwhile } & \text { Anxiety } \\ 2013 & 7.43 & 7.61 & 7.87 & 2.89 \\ 2014 & 7.47 & 7.68 & 7.90 & 2.88 \\ 2015 & 7.52 & 7.74 & 7.96 & 2.78 \\ 2016 & 7.55 & 7.77 & 8.00 & 2.82 \\ 2017 & 7.57 & 7.78 & 7.99 & 2.85 \\ \mathrm{~N} & 277,658 & 277,716 & 277,224 & 277,459\end{array}$


Table 6. OLS Well-being regressions for workers, UK January 2013-December 2017

\begin{tabular}{|c|c|c|c|c|}
\hline & Happiness & Satisfaction & Worthwhile & Anxious \\
\hline Number of under hours & $-.0153(17.85)$ & $-.0278(41.71)$ & $-.0170(26.89)$ & .0272 (22.94) \\
\hline Number of over hours & $-.0128(14.58)$ & $-.0054(8.01)$ & $-.0073(11.38)$ & .0245 (20.18) \\
\hline 2014 & $.0473(3.47)$ & .0583 ( 5.49) & .0388 (3.87) & $-.0164(0.87)$ \\
\hline 2015 & .0921 (7.41) & . $1237(12.80)$ & $.0889(9.72)$ & $-.1019(5.93)$ \\
\hline 2016 & $.1113(8.29)$ & . $1408(13.48)$ & $1204(12.19)$ & $-.0705(3.80)$ \\
\hline 2017 & $.1424(11.98)$ & . $1592(17.20)$ & $.1188(13.58)$ & $-.0556(3.38)$ \\
\hline Age & $-.0422(21.89)$ & -.0615 (41.00) & $-.0337(23.77)$ & .0525 (19.68) \\
\hline $\mathrm{Age}^{2}$ & .0004 (23.69) & $.0006(39.07)$ & .0004 (26.67) & $-.0005(18.68)$ \\
\hline Male & $-.0416(5.06)$ & $-.0562(8.77)$ & $-.1821(30.03)$ & $-.2802(24.57)$ \\
\hline Degree & .0219 & $.0425(6.38)$ & $.0356(5.66)$ & .1891 (15.96) \\
\hline North West & $.0134(0.68)$ & $-.0172(1.12)$ & $.0123(0.85)$ & $-.0027(0.10)$ \\
\hline Merseyside & $-.1066(3.68)$ & $-.0660(2.93)$ & .0220 (1.03) & $.0235(0.59)$ \\
\hline Yorks \& Humber & $-.0013(0.07)$ & .0096 & & .0484 (1.72) \\
\hline East $\mathrm{I}$ & .021 & -.012 & & .0128 \\
\hline West Midlands & 026 & -.010 & -.02 & -.173 \\
\hline East & $-.0014(0.07)$ & $-.0350(2$. & $-.0145(0.93)$ & $.0114(0.39)$ \\
\hline Lond & $-.0594(2.89)$ & -.134 & $-.1395(9.21)$ & $.2137(7.51)$ \\
\hline Sou & -.002 & -.00 & -.02 & 16) \\
\hline Sou & -.008 & -.01 & & $-.00^{-}$ \\
\hline Wales & .0812( & .042 & 22) & $-.0423(1.58)$ \\
\hline Scotland & .0957 (5.12) & $.1046(7$ & 年 $0587(4.27)$ & $-.1654(6.40)$ \\
\hline Nort & .443 & .31 & 89) & -.475 \\
\hline Fore & .163 & .06 & & -.01 \\
\hline Mixed & $-.1654(3.90)$ & -218 & $-.0983(3.15)$ & $.1536(2.62)$ \\
\hline Indian & . $1586(5.79)$ & .0297 ( 1.39$)$ & .0393 (1.95) & $.0685(1.81)$ \\
\hline Pakistan & .08 & -.007 & & . $1087(2.08)$ \\
\hline Ban: & .028 & -.03 & & .130 \\
\hline Chines & -.097 & -.255 & -.276 & $-.0445(0.52)$ \\
\hline Other Asian & . 1335 (3.09) & .027 () 0.82 & .0348 (1.09) & $-.0104(0.17)$ \\
\hline Black & $-.1812(6.72)$ & $-.4040(19.23)$ & $-.1105(5.56)$ & $-.0509(1.36)$ \\
\hline $\operatorname{Rac}$ & -.05 & -0 & & $.0957(1.88)$ \\
\hline Priva & -.010 & -.011 & -.03 & $-.0400(2.57)$ \\
\hline Energ & $-.0756(1.66)$ & $-.0113(0.32)$ & $-.0705(2.11)$ & $-.0623(0.99)$ \\
\hline Manufacturing & $-.1205(3.20)$ & $-.0462(1.58)$ & $-.1444(5.21)$ & $-.0108(0.21)$ \\
\hline Const & $-.0731(1.90)$ & $-.0033(0.11)$ & & $-.1029(1.93)$ \\
\hline Dist & -.125 & -.14 & -.2 & $.0140(0.28)$ \\
\hline Transport & $-.0993(2$ & $-.0845(2$ & $-.1881(6.75)$ & $.0177(0.34)$ \\
\hline Banking \& Finance & $-.0894(2.44)$ & $-.0534(1.87)$ & $-.1522(5.64)$ & $.0524(1.03)$ \\
\hline Public admin & $-.0493(1.34)$ & $-.0619(2.15)$ & $.0669(2.46)$ & $-.0065(0.13)$ \\
\hline Other : & $-.0333(0.8$ & $-.0625(2.07)$ & & $.0275(0.51)$ \\
\hline Tenur & $-.0526(1$ & $.0034(0.16)$ & $.0133(0.65)$ & $.0387(1.01)$ \\
\hline Tenure $\geq 6 \quad \&<12 \mathrm{mths}$ & $-.0415(1.66)$ & $.0377(1.94)$ & $.0100(0.55)$ & $-.0593(1.72)$ \\
\hline Tenure $\geq 1 \quad \&<2$ yrs & $-.0207(0.89)$ & $.0580(3.21)$ & $.0248(1.45)$ & $-.0984(3.06)$ \\
\hline Tenure $\geq 2 \&<5$ yrs & $.0086(0.40)$ & $.1041(6.19)$ & . $0477(2.99)$ & $-.1574(5.26)$ \\
\hline
\end{tabular}




$\begin{array}{lllll}\text { Tenure } \geq 5 \&<10 \mathrm{yrs} & .0241(1.11) & .1641(9.68) & .0862(5.37) & -.2022(6.70) \\ \text { Tenure } \geq 10 \&<20 \mathrm{yrs} & .0429(1.98) & .1927(11.42) & .0991(6.21) & -.1956(6.52) \\ \text { Tenure } \geq 20 \mathrm{yrs} & .0731(3.19) & .2276(12.74) & .1176(6.96) & -.1522(4.79) \\ \text { Self-employed } & .0961(8.34) & .0303(3.39) & .1612(19.01) & -.0274(1.72) \\ \text { Constant } & 8.3118 & 8.9977 & 8.6212 & 1.8961 \\ & & & & \\ \mathrm{~N} & 274,170 & 274,229 & 273,748 & 273,983 \\ \text { Adjusted } \mathrm{R}^{2} & .0083 & .0208 & .0259 & .0117\end{array}$

Notes: t-statistics in parentheses. Excluded categories; North East; Christian; single and 2013. Region refers to residence. 
Table 7. Proportion depressed, UK, January 2013- March 2018-n=1,624,298

Out of the labor force

Men

2.8

Women

Homemaker

4.6

3.8

Student

1.0

5.0

Retired

0.8

2.4

Unemployed

5.1

1.5

Part-time: student

1.4

7.3

Part-time: ill or disabled

6.0

2.7

Part-time: could not find full-time job

2.6

8.2

Part-time: did not want full-time job

Part-time: no reason given

1.8

4.2

Full-time

4.0

3.1

Unpaid family worker

1.4

5.8

1.9

2.6

All

2.0

3.2

3.4

\section{Workers only}

Employed

1.5

3.1

Employees

1.5

3.0

Self-employed

1.3

2.7

Under hours $=0$

1.5

2.8

Under hours $>0$

2.4

4.3

Under hours 1-4

2.2

3.7

Under hours 5-9

2.1

4.0

Under hours 10-19

2.4

Under hours $\geq 20$

2.7

4.4

Over hours $=0$

2.2

4.9

Over hours $>0$

Over hours 1-4

1.7

3.7

Over hours 5-9

1.7

3.0

1.8

3.5

Over hours 10-19

1.7

3.4

Over hours $\geq 20$

1.5

2.7

2.9 
Table 8. Percentage reporting being depressed, January 1997-April 2018

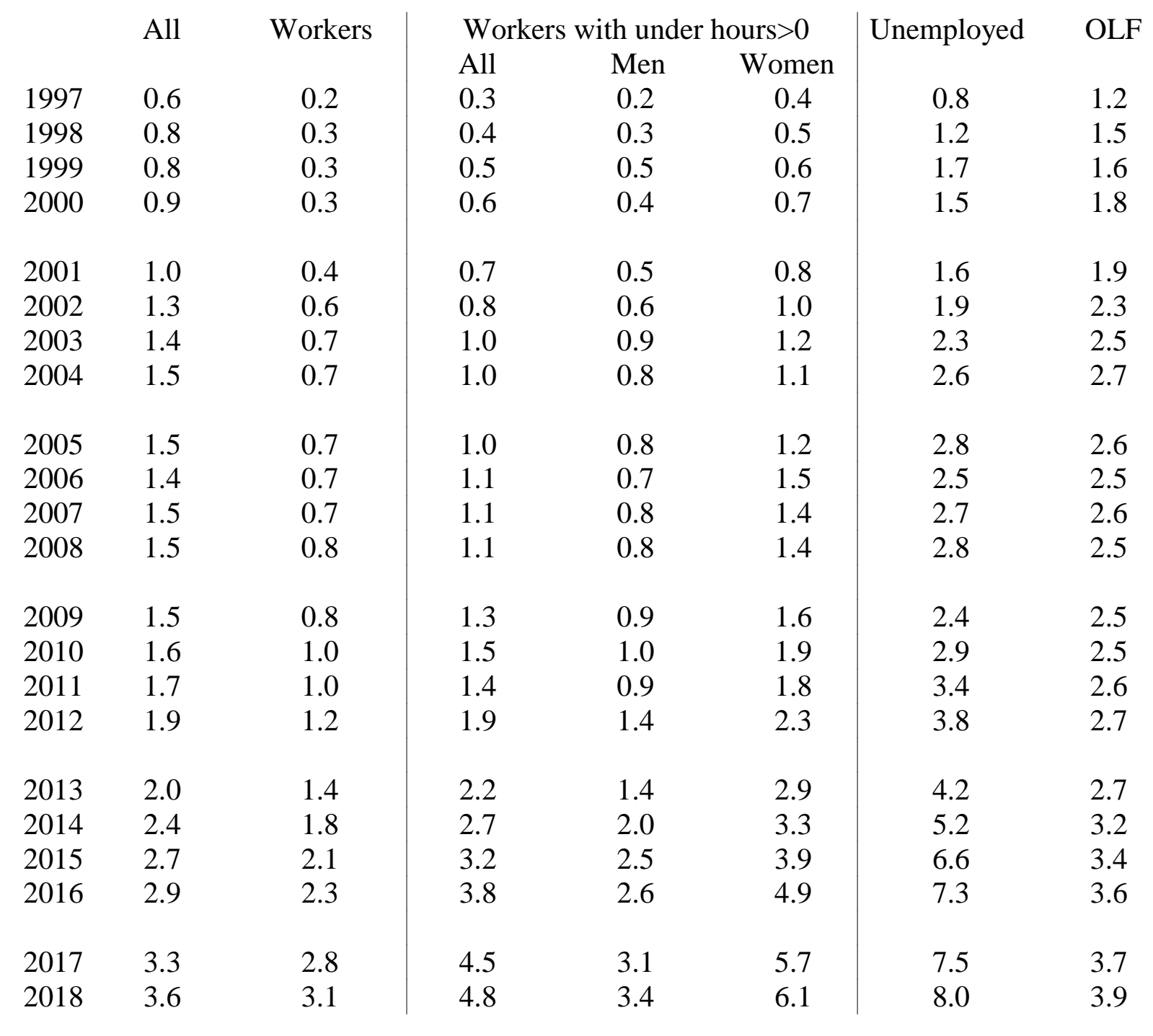


Table 9. Probability of being depressed (OLS), 2004-2018, workers only

\begin{tabular}{|c|c|c|c|}
\hline Number of under hours & $.00025(22.41)$ & $.00008(5.65)$ & \\
\hline Number of over hours & $.00012(7.10)$ & $\mathrm{n} / \mathrm{a}$ & $.00002(0.70)$ \\
\hline Self-employed & $-.0007(3.80)$ & $.0017(2.08)$ & $-.0033(5.44)$ \\
\hline 2005 & $.0003(1.21)$ & $.0009(0.80)$ & $-.0008(0.96)$ \\
\hline 2006 & $.0002(0.94)$ & $.0023(2.04)$ & $-.0002(0.27)$ \\
\hline 2007 & $.0008(3.24)$ & $.0027(2.39)$ & $-.0001(0.18)$ \\
\hline 2008 & $.0010(3.92)$ & $.0026(2.32)$ & $-.0000(0.03)$ \\
\hline 2009 & $.0016(5.93)$ & $.0049(4.34)$ & $.0006(0.63)$ \\
\hline 2010 & $.0031(10.76)$ & $.0062(5.37)$ & $.0023(2.27)$ \\
\hline 2011 & $.0041(13.51)$ & $.0049(4.38)$ & $.0048(4.33)$ \\
\hline 2012 & $.0060(18.88)$ & $.0106(8.66)$ & $.0076(6.44)$ \\
\hline 2013 & $.0080(23.72)$ & $.0148(11.09)$ & $.0072(6.17)$ \\
\hline 2014 & $.0117(32.06)$ & $.0189(13.41)$ & $.0107(8.82)$ \\
\hline 2015 & $.0145(37.06)$ & $.0252(16.00)$ & $.0128(10.12)$ \\
\hline 2016 & $.0168(41.59)$ & $.0306(18.12)$ & $.0171(12.96)$ \\
\hline 2017 & $.0221(54.28)$ & $.0383(22.43)$ & $.0201(15.57)$ \\
\hline 2018 & $.0255(29.20)$ & $.0415(11.53)$ & $.0300(10.32)$ \\
\hline Male & $-.0077(55.29)$ & $-.0098(17.44)$ & $.0045(1.26)$ \\
\hline Age $20-24$ & .0037 (7.99) & $.0038(3.14)$ & $.0059(1.75)$ \\
\hline Age $25-29$ & $.0055(12.02)$ & $.0088(6.79)$ & $.0036(1.12)$ \\
\hline Age $30-34$ & $.0061(13.61)$ & $.0121(9.07)$ & $.0047(1.44)$ \\
\hline Age 35-39 & $.0066(14.85)$ & $.0089(7.00)$ & $.0060(1.85)$ \\
\hline Age $40-44$ & $.0076(17.08)$ & $.0123(9.53)$ & $.0038(1.19)$ \\
\hline Age $45-49$ & $.0065(14.65)$ & $.0117(8.93)$ & $.0017(0.54)$ \\
\hline Age $50-54$ & $.0051(11.53)$ & $.0090(6.60)$ & $-.0021(0.65)$ \\
\hline Age $55-59$ & $.0026(5.96)$ & $.0091(6.19)$ & $-.0043(1.32)$ \\
\hline Age $60-64$ & $-.0001(0.38)$ & $.0010(0.66)$ & $-.0092(2.78)$ \\
\hline Age $65-69$ & $-.0043(8.68)$ & $-.0044(2.03)$ & $-.0102(2.80)$ \\
\hline Age $>=70$ & $-.0064(10.92)$ & $-.0173(14.51)$ & $-.0057(12.20)$ \\
\hline Mixed race & $.0011(1.19)$ & $.0002(0.09)$ & $.0045(1.21)$ \\
\hline Asian & $-.0088(36.02$ & $-.0143(18.16)$ & $-.0093(8.58)$ \\
\hline Chinese & $-.0099(14.87)$ & $-.0176(8.8)$ & $-.0115(4.40)$ \\
\hline Black & $-.0091(26.05)$ & $-.0138(12.36)$ & $-.0114(8.82)$ \\
\hline Other races & $-.0056(11.00)$ & $-.0132(10.06)$ & $-.0087(4.20)$ \\
\hline Rest of North & $-.0026(3.86)$ & $.0023(0.85)$ & $-.0015(0.75)$ \\
\hline South Yorkshire & $.0010(1.34)$ & $-.0018(0.63)$ & $.0023(0.98)$ \\
\hline West Yorkshire & $-.0010(1.51)$ & $-.0010(0.40)$ & $.0026(1.23)$ \\
\hline Rest Yorkshire \& Humber & $-.0030(4.34)$ & $-.0019(0.73)$ & $-.0053(2.61)$ \\
\hline East Midlands & $-.0026(4.31)$ & $-.0034(1.48)$ & $.0000(0.02)$ \\
\hline East Anglia & $-.0014(2.26)$ & $.0000(0.02)$ & $.0015(0.76)$ \\
\hline Central London & $-.0076(12.37)$ & $-.0106(4.36)$ & $-.0076(4.08)$ \\
\hline Inner London & $-.0048(7.36)$ & $-.0088(3.60)$ & $-.0041(1.96)$ \\
\hline Outer London & $-.0058(9.44)$ & $-.0092(3.95)$ & $-.0028(1.48)$ \\
\hline Rest of South East & $-.0027(4.81)$ & $-.0024(1.08)$ & $-.0015(0.86)$ \\
\hline
\end{tabular}




$\begin{array}{llll}\text { South West } & -.0022(3.70) & -.0031(1.33) & -.0004(0.22) \\ \text { West Midland (Met county) } & -.0038(5.95) & -.0087(3.64) & -.0012(0.63) \\ \text { Rest West Midlands } & -.0034(5.33) & -.0038(1.50) & -.0003(0.19) \\ \text { Greater Manchester } & -.0031(4.83) & -.0040(1.63) & .0030(1.42) \\ \text { Merseyside } & -.0031(4.21) & .0004(0.16) & .0010(0.42) \\ \text { Rest North West } & -.0041(6.46) & -.0018(0.72) & -.0020(1.01) \\ \text { Wales } & -.0015(2.36) & .0007(0.29) & .0012(0.61) \\ \text { Strathclyde } & -.0009(1.42) & -.0050(1.95) & .0018(0.86) \\ \text { Rest of Scotland } & -.0037(6.04) & -.0040(1.67) & -.0022(1.17) \\ \text { Northern Ireland } & -.0061(9.59) & -.0080(2.91) & -.0038(1.77) \\ \text { Outside UK } & -.0134(14.76 & -.0191(2.89) & -.0146(4.71) \\ \text { Age left school } & -.0002(9.81) & -.0004(3.77) & .0000(0.08) \\ \text { Constant } & .0136 & .0159 & .0115 \\ \mathrm{~N} & 2,739,813 & 267,372 & 277,289 \\ \mathrm{R}^{2} & .0066 & .0106 & .0060\end{array}$

Notes: workers only. Column 2 is for workers who want $>0$ additional hours (undhrs $>0$ ) and column 3 for workers whoi want $>0$ fewer hours (ovhrs $>0$ ). Region variables relates to region of work. Excluded categories: ages 16-19; Tyne \& Wear; 2004 and white. T-statistics in parentheses with robust standard errors.

Source: LFS 2004-2018 
Table 10. Antidepressant drugs consumption, 2000 and 2015 (defined daily dose per 1000 per day)

$\begin{array}{lrrc} & 2000 & 2015 & 2015 / 2000 \text { multiple } \\ \text { Portugal } & 32.5 & 95.1 & 2.9 \\ \text { Germany } & 20.7 & 56.4 & 2.7 \\ \text { Spain } & 28.2 & 73.1 & 2.6 \\ \text { Greece } & 18.9 & 48.1 & 2.5 \\ \text { United Kingdom } & 37.6 & 94.2 & 2.5 \\ \text { Italy } & 19.6 & 46.5 & 2.4 \\ \text { Australia } & 45.4 & 104.2 & 2.3 \\ \text { Denmark } & 35.2 & 77.0 & 2.2 \\ \text { Sweden } & 44.8 & 92.5 & 2.1 \\ \text { OECD29 } & 30.7 & 60.3 & 2.0 \\ \text { Belgium } & 38.8 & 78.3 & 2.0 \\ \text { Finland } & 35.5 & 68.2 & 1.9 \\ \text { Iceland } & 70.5 & 129.6 & 1.8 \\ \text { Netherlands } & 31.4 & 45.1 & 1.4 \\ \text { France } & 39.5 & 49.8 & 1.3\end{array}$

Source: Figures 10.8 and 10.9, Health at a Glance 2017, OECD 


\section{References}

Adams, A. and Prassi, J., 2018. Zero-hours work in the United Kingdom. Conditions of Work and Employment Series, No. 101, International Labour Organization. https://www.ilo.org/wcmsp5/groups/public/---ed_protect/---protrav/--travail/documents/publication/wcms_624965.pdf

Angrave, D. and Charlwood, A., 2015. What is the relationship between long working hours, overemployment, underemployment and the subjective well-being of workers? Longitudinal evidence from the UK. Human Relations, 68(9),1491-1515.

Angrist, J.D., 2001. Estimation of limited dependent variable models with dummy endogenous regressors: simple strategies for empirical practice. Journal of Business and Economic Statistics, 19(1), 2-28.

Baxter, A.J., Scott, K.M. Ferrari, A.J., Norman, R.E., Vos, T. and Whiteford, H.A., 2014. Challenging the myth of an "epidemic" of common mental disorders: trends in the global prevalence of anxiety and depression between 1990 and 2010. Depression and Anxiety, 31, 506516.

Bell, D. N., and Blanchflower, D.G., 2019. Underemployment in the US and Europe. Industrial and Labor Relations Review, forthcoming.

Bell, D.N.F. and Blanchflower, D.G., 2018a. Underemployment and the lack of wage pressure in the UK. National Institute Economic Review, 243(1), R53-R61.

Bell, D. N., and Blanchflower, D.G., 2018b. The lack of wage growth and the falling NAIRU. National Institute Economic Review, 244(2), R1-R16.

Bell, D.N.F. and Blanchflower, D.G., 2014. Labour market slack in the UK. National Institute Economic Review, 229(3), F4-F11.

Bell, D.N.F. and Blanchflower, D.G., 2013. 'Underemployment in the UK revisited. National Institute Economic Review, 224(2), F8-F22.

Bell, D.N.F. and Blanchflower, D.G., 2011. Youth underemployment in the UK in the Great Recession. National Institute Economic Review, 222(1), R1-R11.

Belotti, F., Deb, P., Manning, W.G. and Norton, E.C., 2015. Two-part models. Stata Journal, 15(1), 3-20.

Blanchflower, D.G., 2019. Not Working: Where Have All The Good Jobs Gone? Princeton University Press.

Blanchflower, , D.G., 2015. Self-employment Across Countries in the Great Recession of 20082014. Randstad, Amsterdam. 
Blanchflower, , D.G., 1991. Fear, unemployment and pay flexibility. The Economic Journal, 101(406), 483-496.

Blanchflower, D.G. and Oswald, A.J., 2018. Is there a midlife psychological low? Two approaches (with and without controls) in six modern data sets on 1.3 million citizens? Paper presented at NBER conference Measurement and Tracking of Subjective Well-Being for Aging Research, July $28,2018$.

https://www.dartmouth.edu/ blnchflr/papers/14\%20August\%20BlanchOswald\%20U\%20shape \%20Midlife\%20Low\%202017.pdf

Blanchflower, D.G. and Oswald, A.J., 2016. Antidepressants and age: a new form of evidence for U-shaped well-being through life. Journal of Economic Behavior and Organization, 127, 46-58.

Blanchflower, D.G. and Oswald, A.J., 2008. Is well-being U-shaped over the life cycle? Social Science and Medicine, 66(8), 1733-1749.

Blanchflower, D.G. and Shadforth, C. 2009. The Economic Journal, 119(535), F136-F182.

Blundell, R., and Shephard, A., 2011. Employment, hours of work and the optimal taxation of lowincome families. The Review of Economic Studies, 79(2), 481-510.

Datta, N., Giupponi, G. and Machin, S.J., 2018. Zero hours contracts and labour market policy, paper presented at $68^{\text {th }}$ Economic Policy Panel, Vienna, $4^{\text {th }}-5^{\text {th }}$ October.

Dooley D. and Prause, J., 1998. Underemployment and alcohol misuse in the National Longitudinal Survey of Youth. Journal of Studies on Alcohol, 59, 669-680.

Dooley D., Prause, J. and Ham-Rowbottom, K.A., 2000. Underemployment and depression: longitudinal relationships. Journal of Health and Social Behavior, 41(4), 421-36.

European Commission, 2018. Labour Market and Wage Developments in Europe, Annual Review 2018. Luxembourg: Publications Office of the European Union.

https://www.eubusiness.com/Books/labour-market-18

Friedland, D.S. and Price, R.H., 2003. Underemployment: consequences for the health and wellbeing of workers. American Journal of Community Psychology, 32(1/2), September, 33-45.

Gilfillan, G., 2018. Characteristics and use of casual employees in Australia. Research Paper Series 2017-2018, Parliament of Australia.

https://www.aph.gov.au/About_Parliament/Parliamentary_Departments/Parliamentary_Library/p ubs/rp/rp1718/CasualEmployeesAustralia

Heyes, J., Tomlinson, M. and Whitworth, A., 2017. Underemployment and well-being in the UK before and after the Great Recession. Work, Employment and Society, 31(1), 71-89. 
IMF, 2017. World Economic Outlook, October, Washington D.C..

Jorm, A. F., Patten, S.B., Brugha, T.S. and Mojtabai, 2017. Has increased provision of treatment reduced the prevalence of common mental disorders? Review of the evidence from four countries. World Psychiatry, 16(1), 90-99.

Kamerade, D. and Richardson, H., 2018. Gender segregation, underemployment and subjective well-being in the UK labour market. Human Relations, 71(2), 285-309.

Kügler, A., Schönberg, U. and Schreiner, R., 2018. Productivity growth, wage growth and unions. Paper given at ECB Forum on Central Banking Price and wage-setting in advanced economies, Sintra, Portugal, 18-20 June 2018.

https://www.ecb.europa.eu/pub/pdf/sintra/ecb.forumcentbank201810.en.pdf

Lewis, H. G., 1969. Employer interests in employee hours of work. Unpublished paper, University of Chicago.

Mars, B., Heron, J.,Kessler, D., Davies, N.M., Martin, R.M.,Thomas, K.H., Gunnell, D., 2017. Influences on antidepressant prescribing trends in the UK: 1995-2011. Social Psychiatry and Psychiatric Epidemiology, 52(2), 193-200.

New Economics Foundation, 2012. Wellbeing patterns uncovered: An analysis of UK data, London. https://neweconomics.org/2012/11/well-patterns-uncovered

OECD, 2018. Employment Outlook, 2018, Paris.

OECD, 2017. Health at a Glance, 2017, Paris.

Oi, W., 1983. The fixed employment costs of specialized labor. In: J. Triplett (Ed.). The Measurement of Labor Cost, Chicago: University of Chicago Press, 63-122.

Prause, J., and Dooley, D., 1997. Effect of underemployment on school-leaver's self-esteem. Journal of Adolescence, 20, 243-260.

Pratt, L.A., Brody, D.J. and Gu, Q., 2017. Antidepressant use among persons aged 12 and over: United States, 2011-2014. NCHS Data Brief No. 283, August.

Rauch, J., 2017. The Happiness Curve: Why Life Gets Better after Midlife. Thomas Dunne.

Robone, S., Jones, A.M. and Rice, N., 2011. Contractual conditions, working conditions and their impact on health and well-being. The European Journal of Health Economics, 12(5), 429-444.

Tam, H., 2010. Characteristics of the underemployed and the overemployed. Economic and Labour Market Review, 4(7), Office for National Statistics, London. 
Viola, S. and Moncrieff, J., 2016. Claims for sickness and disability benefits owing to mental disorders in the UK: trends from 1995 to 2014. BJPsych Open, 2(1), 18-24.

Weale, M., 2014. Slack and the labour market. Speech given at the Thames Valley Chamber of Commerce, 20th March, http://www.bankofengland.co.uk/publications/Documents/speeches/2014/speech716.pdf

Wilkins, R., 2007. The consequences of underemployment for the underemployed. Journal of Industrial Relations, 49, 247-75.

Wooden, M., Warren, D. and Drago, R., 2009. Working time mismatch and subjective well-being. British Journal of Industrial Relations, 47(1), 147-179.

Wunder, C. and Heineck, G., 2013. Working time preferences, hours mismatch and well-being of couples: Are there spillovers? Labour Economics, 24, 244-252

Zapf, D., Dormann, C. and Frese, M., 1996. Longitudinal studies in organizational stress research: A review of the literature with reference to methodological issues. Journal of Occupational Health Psychology, 1, 145-169. 
Chart 1. Monthly Underemployment and Unemployment rates, UK, 1992-2018

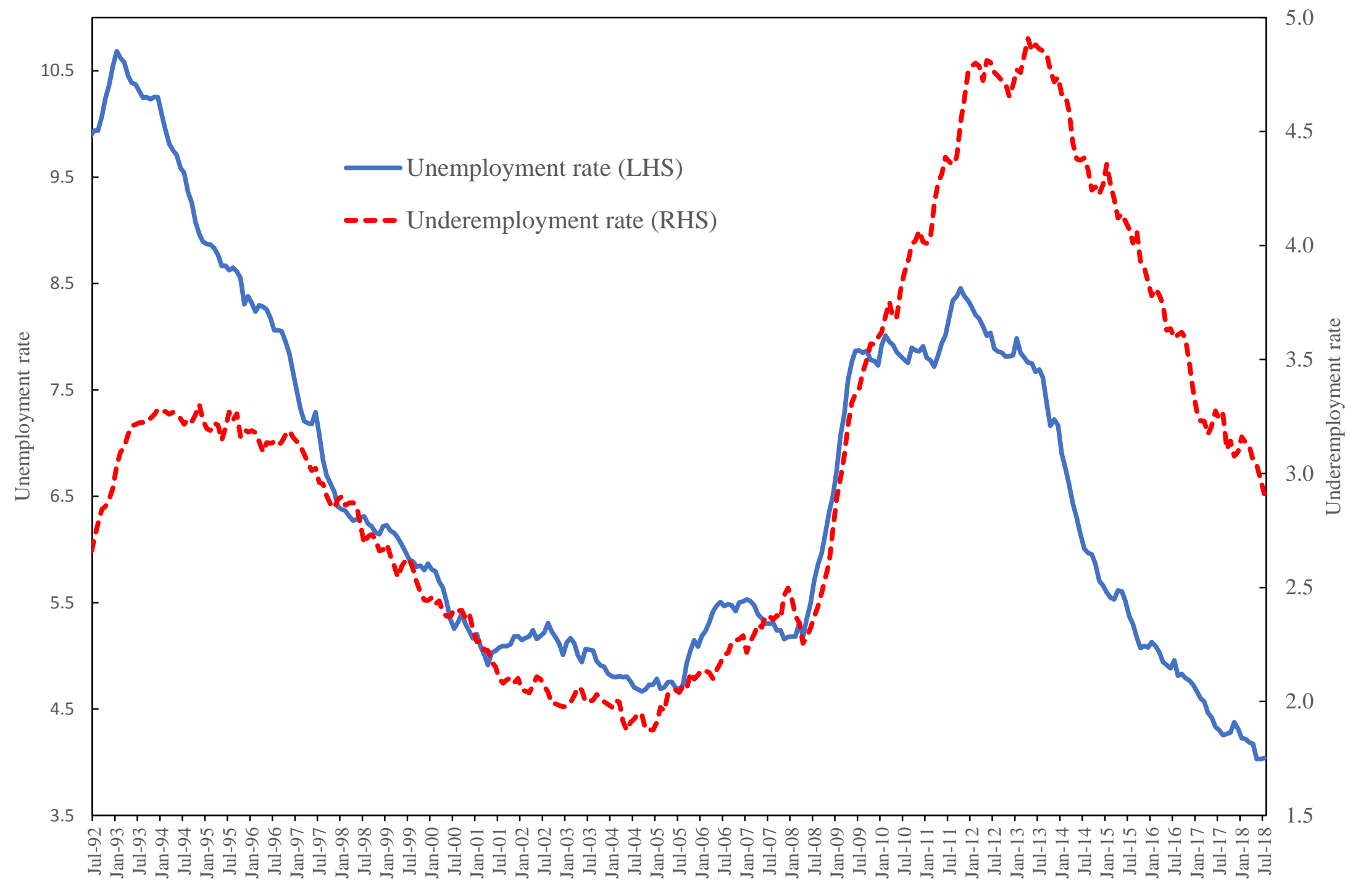




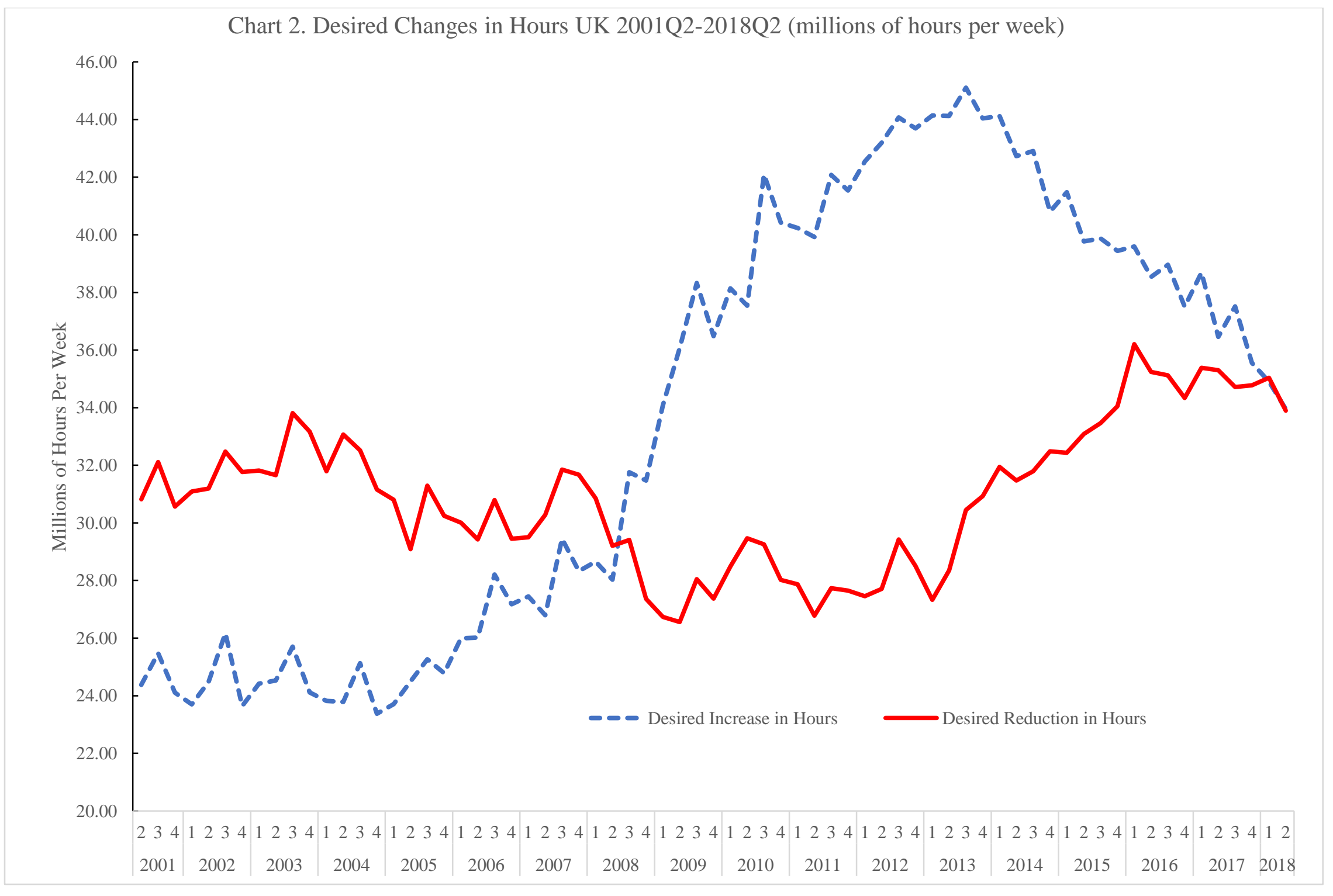




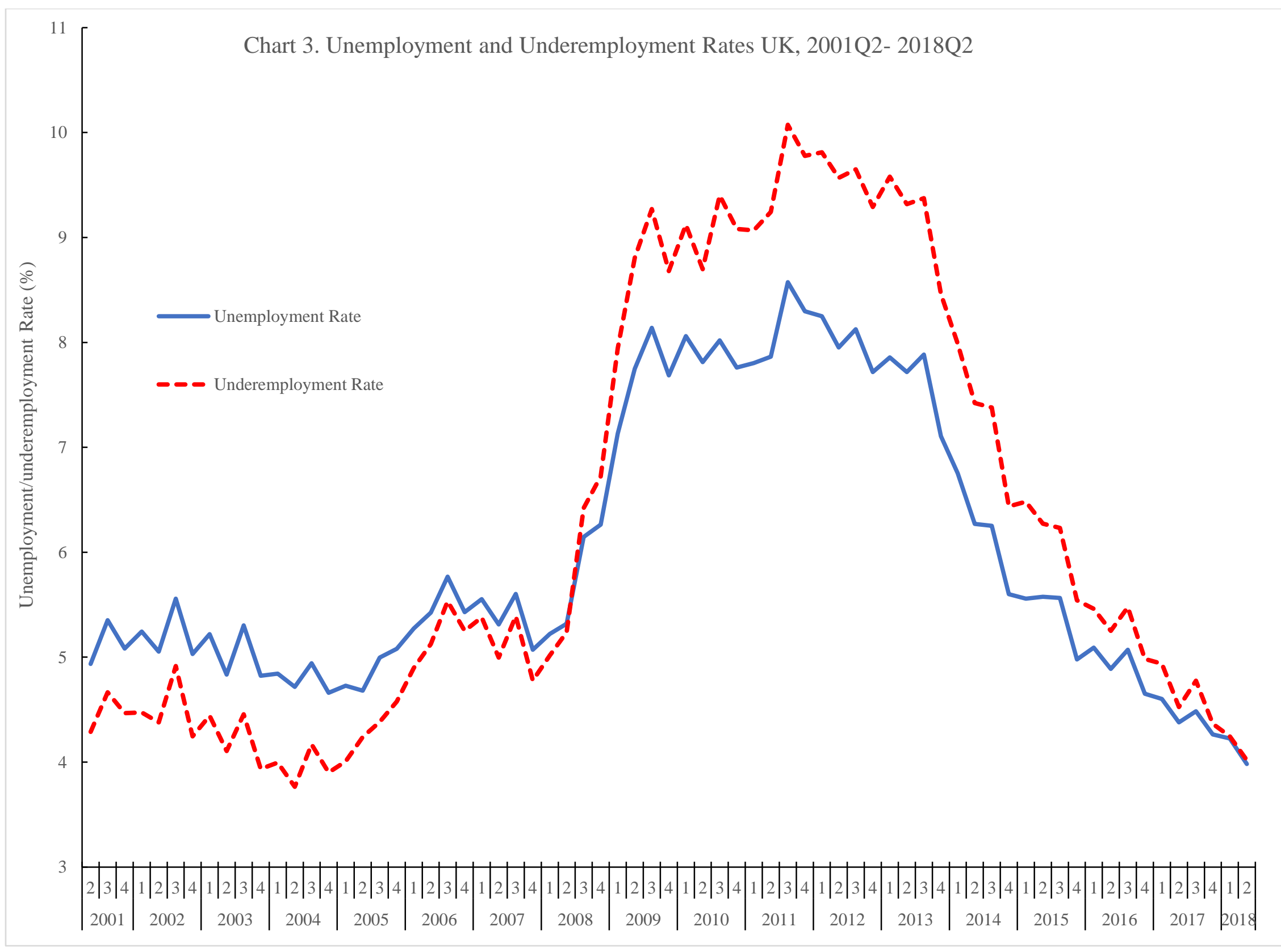




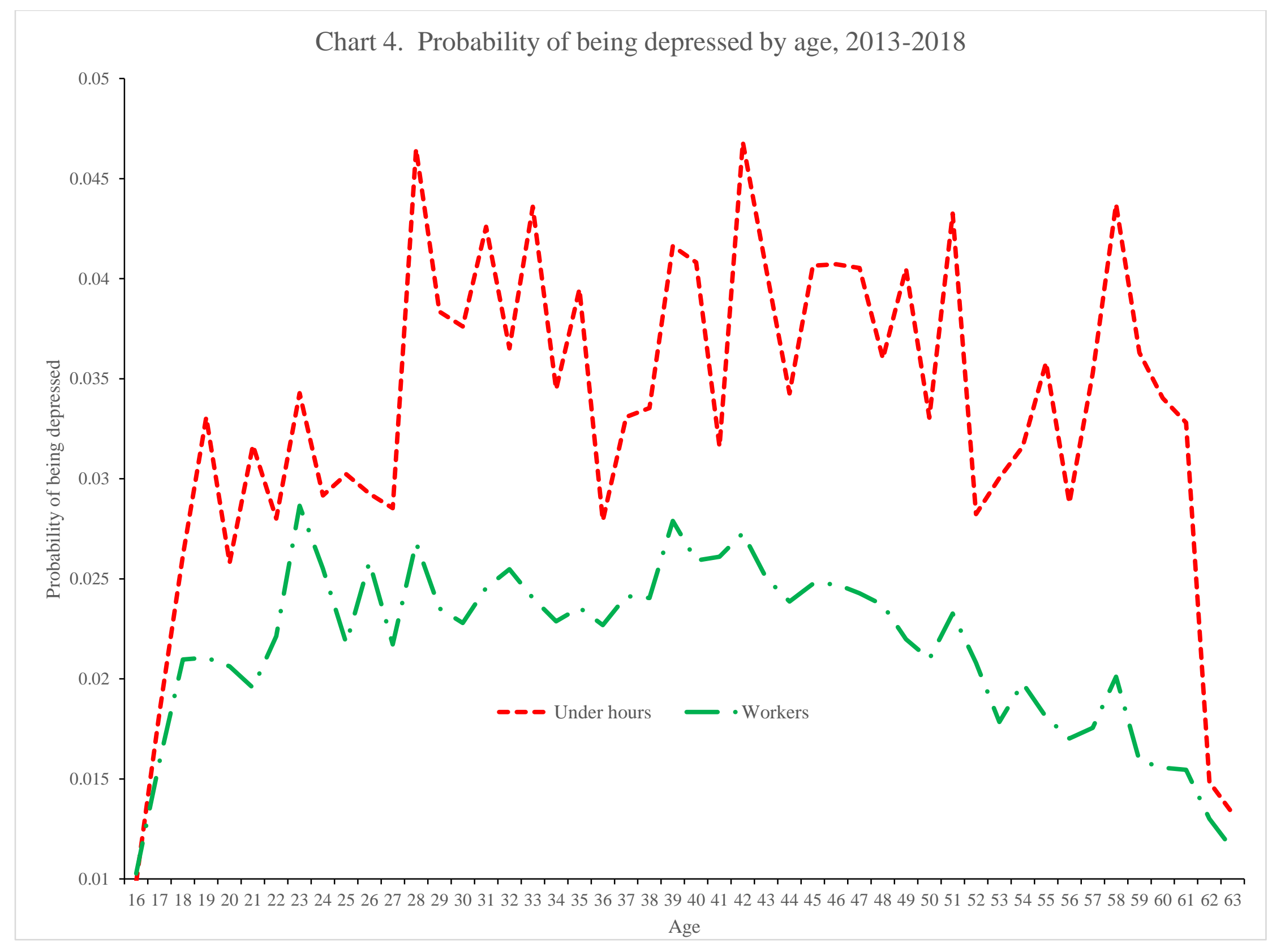




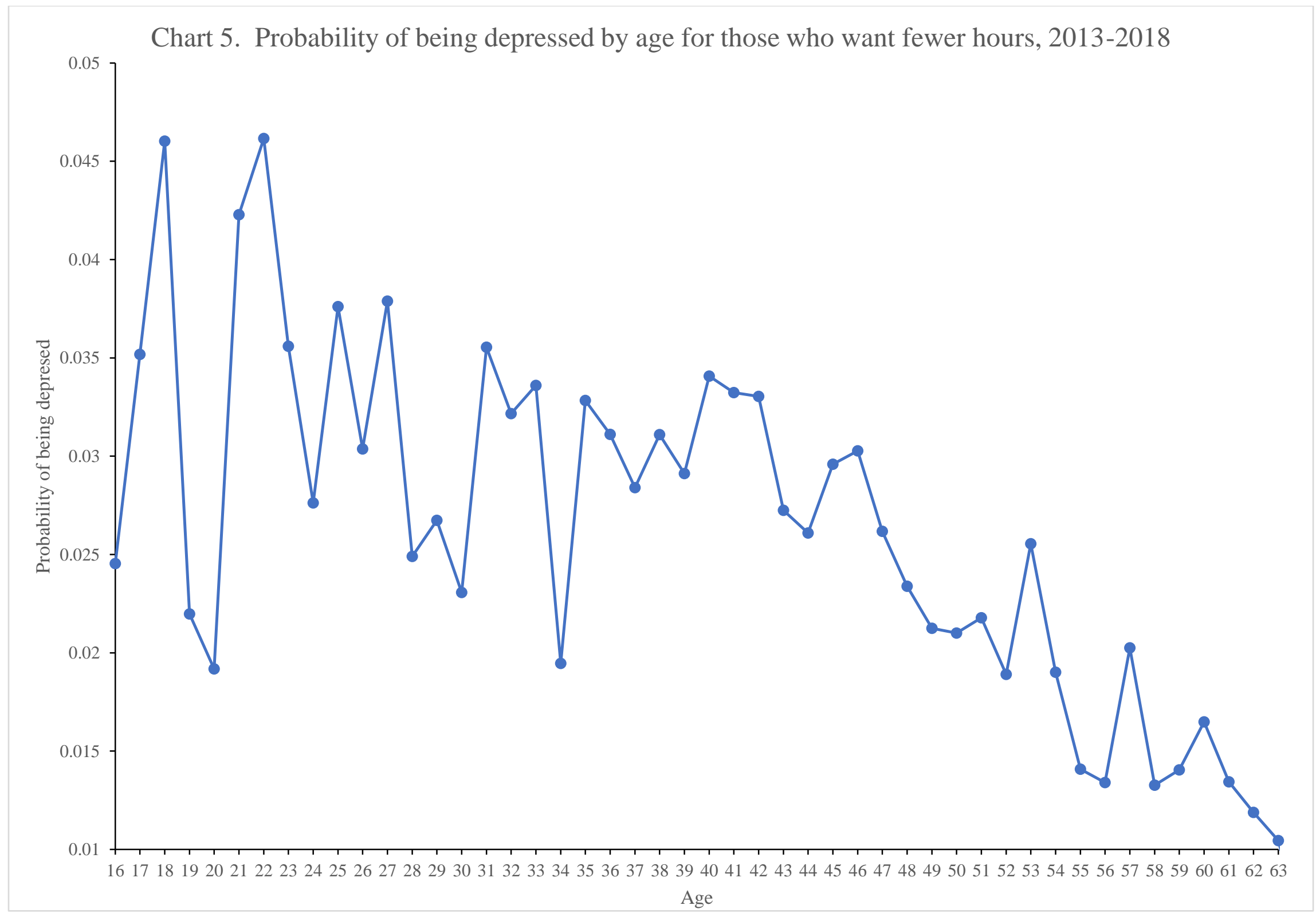

32 